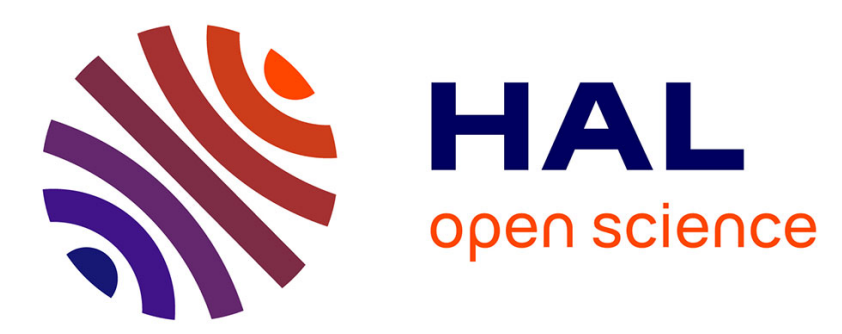

\title{
Occupation and Environmental Context of a Prehistoric and Protohistoric Settlement on the Corsican East Coast
}

Nathalie Marini

\section{To cite this version:}

Nathalie Marini. Occupation and Environmental Context of a Prehistoric and Protohistoric Settlement on the Corsican East Coast. Jul 2006, pp.461-466. hal-00138444

\section{HAL Id: hal-00138444 \\ https://hal.science/hal-00138444}

Submitted on 30 Mar 2007

HAL is a multi-disciplinary open access archive for the deposit and dissemination of scientific research documents, whether they are published or not. The documents may come from teaching and research institutions in France or abroad, or from public or private research centers.
L'archive ouverte pluridisciplinaire HAL, est destinée au dépôt et à la diffusion de documents scientifiques de niveau recherche, publiés ou non, émanant des établissements d'enseignement et de recherche français ou étrangers, des laboratoires publics ou privés. 


\title{
Occupation and Environmental Context of a Prehistoric and Protohistoric Settlement on the Corsican East Coast
}

\author{
Nathalie Marini \\ Groupe de Recherches Préhistoriques et Protohistoriques \\ Université de Corse Pascal Paoli \\ Caserne Padoue 20250 Corte \\ FRANCE \\ marini@univ-corse.fr
}

\begin{abstract}
The site of Costa di u Monte is on the east coast of Corsica. It occupies a privileged position within the Tyrrhenian area, in a region where for the island, the archeological sites are rare and little studied. This settlement, very wide, was occupied during the Neolithic, the Bronze Age, the Iron Age and until the Contemporary Time. For the prehistoric and protohistoric periods, the excavations enabled to identify levels of habitats and a burial. These occupations left an abundant material, ceramic, lithic (obsidian) and metal in particular. These vestiges attest to the exploitation of the immediate environment of the site but also to the existence of relationships between other Mediterranean areas.
\end{abstract}

Index Terms--Bronze Age, Iron Age, ceramics, Corsica, environment, habitat, Mediterranean, Neolithic, obsidian, burial.

\section{INTRODUCTION}

The site of Costa di u Monte (Poggio-Mezzana Municipality, Haute-Corse) is on the eastern coast of Corsica, between the coastal plain and the massif of Castagniccia (Fig.1). In this area, i.e. between the basins of Tavignanu and Golu, the plain is reduced sometimes to less than one kilometer. The landscape is compartmentalized and the unevenness is rather important. The site is on a steepslopes hill which reaches $213 \mathrm{~m}$ at its highest point, only 2 $\mathrm{km}$ from the sea. It is composed of a large-sized summit plateau ( 2 hectares in average) and of many terraces which are prolonged until the bottom of the relief, in particular on the east side; in the west the slopes are stiffer.

The site went through several phases of occupation since the Neolithic, the Bronze Age, the Iron Age and until the Contemporary Time. At the time of the survey many remains were collected (ceramic, knapped stones and polished lithic), the principal zones of collecting are the plateau and the adjacent terraces. Structures also attest to various activities which followed one another, in particular the retaining walls of terraces or of parcel delimitation.

Our study concerns prehistoric and protohistoric occupations. For these periods, this site which covers a vast area can help us apprehend better certain questions, in particular concerning the exchanges in the Tyrrhenian area. One of the problematic of the study thus results in the geographical position of the site, on one of the human ways of passage and raw material circulation. Moreover, the sites excavated in this area of the island are rare, as well as the settlement with a large surface area covering as many times.

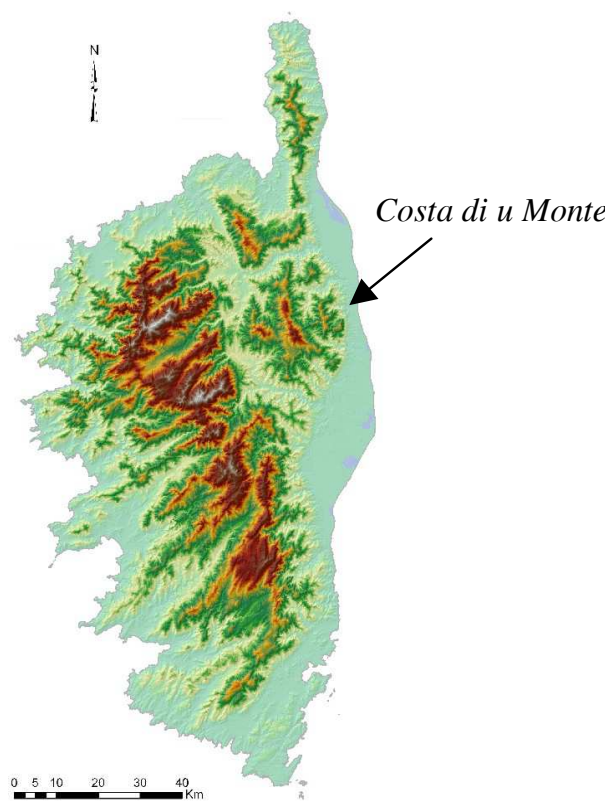

Fig. 1. Map of Corsica, localisation of the site.

\section{THE EXCAVATION}

Three test excavations were carried out in various sectors of the southern zone of the plateau [1]-[2], in order to evaluate the preservation of the archaeological layers ${ }^{1}$ (Fig. 2).

1 This work was financed by the State, the Service Régional de l'Archéologie, the Groupement Régional des Sociétés Archéologiques de Corse, the Collectivité Territoriale de Corse and the Municipality of PoggioMezzana.

The studies of material are carried out at the Université de Corse by A Nonza-Micaelli for ceramics, J. Sicurani for knapped stones and A. Colonna for polished lithic. 


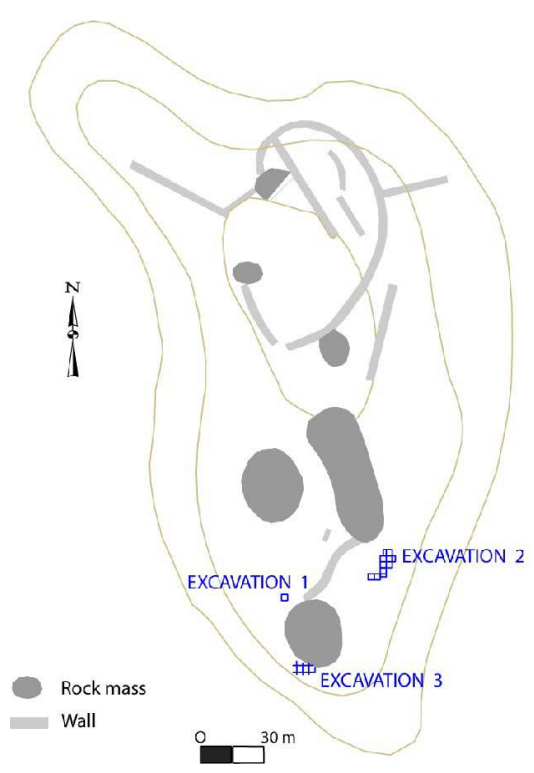

Fig. 2. Map of the site and localisation of the excavations.

\section{A. The First Excavation}

The first test excavation $\left(1 \mathrm{~m}^{2}\right)$ was established on the plateau on the west side. It enabled to bring to light two levels dating from the Bronze Age. A structure seems to appear, it is made up of stones from 15 to $20 \mathrm{~cm}$ flat posed and laid out in half-circle. Another part of the survey is occupied by bed rock. The material is primarily composed of ceramics among which characteristic elements, like a shard presenting a cordon with finger-nail impressions and two flat rims. The discovery of cob and an installation lets us suggest the presence of a construction in these layers.

\section{B. The Second Excavation}

The second excavation $\left(9 \mathrm{~m}^{2}\right)$, is on a terrace on the south-east side. Layer II enabled to bring to light a level including structures dating from the Bronze Age, but it seems partly altered. Indeed, many lithic vestiges, rather characteristic of the Neolithic, were discovered, in particular in the northern zone of the excavation.

We discovered an alignment of 4 blocks over $4,80 \mathrm{~m}$ in length. These blocks are most probably of anthropic origin. They delimit a space in which is a pavement. The ground of this layer is marked by the association of nodules of cob, coals and gravels.

For the vestiges, the elements of cob are numerous, they sometimes present plane faces. They often carry several parallel or crossed traces of wattle, which indicate the size of the branches used (from 3 to $1 \mathrm{~cm}$ ).

The ceramic vestiges are very numerous, we have discovered 660 of them. Some were found flat in the ground, in particular a fragment of paunch $(20 \mathrm{~cm}$ by $15 \mathrm{~cm})$ very fractured, carrying finger-nail impressions. The handles are in majority made of "ruban" (Fig. 3, n¹7); the bases are flat; the decorations are mostly cordons, some of which have finger-nail impressions (Fig. 3, $n^{\circ} 12-15$ ); the rims are in majority everted, with lip in internal bevel or inverted (Fig. 3, $\left.\mathrm{n}^{\circ} 18-22\right)$.

The lithic vestiges are in great majority made of obsidian (168 elements). Many are debris, we can note the preponderance of fragments of blades, microblades or flakeblades (53 elements) (Fig. 3, $\left.\mathrm{n}^{\circ} 2,3,8-11\right)$. We also brought to light two fragments of blade cores (Fig. $3, \mathrm{n}^{\circ} 1$ ), as well as a burin on a proximal part of blade (Fig. 3, ${ }^{\circ} 4$ ), a borer on a distal fragment of microblade (Fig. $3, n^{\circ} 6$ ), a microborer on a microblade and a stemmed projectile point with obtuse shoulders (Fig. 3, $\mathrm{n}^{\circ}$ ). We also discovered hyaline quartz and an element in rhyolite which do not present any trace of retouch. Pebbles often in quartz, a fragment of pumice and a fragment of ground stone re-used in a structure were discovered.

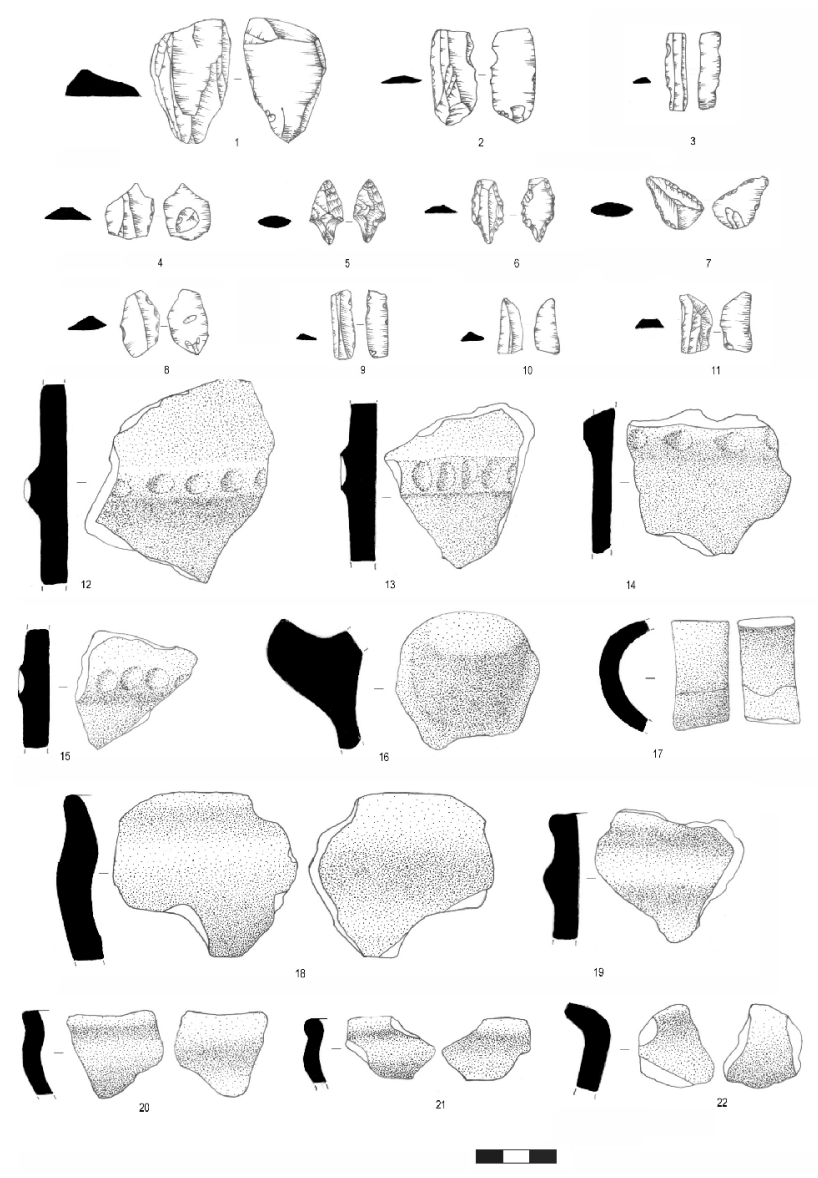

Fig. 3. Material of the second excavation. 1-11 : obsidian artefacts; 12-15 : decorated shards; 16 et $17:$ handles; $18-22:$ rims.

This layer thus corresponds to a level of organized occupation. However, we can distinguish two sectors which differ by nature from the structures and vestiges; only fragments of cob are found on the whole of the excavation. 
First of all, the central zone and the southern sector can be brought together by the presence of aligned blocks, the nature of the vestiges or the continuity of the pavement; the ground is of the same composition and the ceramic vestiges discovered seem in place.

On the contrary, the structures and the vestiges present in the northern sector of the excavation are very different. The stones are put straight, the obsidians are numerous, ceramics are more often in thin paste and no ceramic characteristic of the Bronze Age is present on the ground of this layer in this zone.

Several assumptions are possible, either these two sectors are of different times, or this layer is a level of the Bronze Age which was strongly disrupted in the northern zone, thus altering subjacent Neolithic layers.

In the continuity of this excavation, we carried out a stratigraphic excavation, which showed an important sedimentary filling. Two levels were recognized, the collected vestiges are ceramics, fragments of cob and obsidians. But the dating of these levels remains dubious, ceramics do not enable to conclude that it is a homogeneous Neolithic occupation.

\section{The Third Excavation}

Excavation 3 was established in a small "shelter", from approximately $7 \mathrm{~m}^{2}$ (Fig. 4). It was built by the stones set on edge and the construction of a low wall. The rock which forms the cover of the shelter, covers only one part of the excavated zone. The whole is largely open on the outside and the qualifier "of shelter", has sense only in the local geological context, where this type of structure is rare and of reduced sizes.

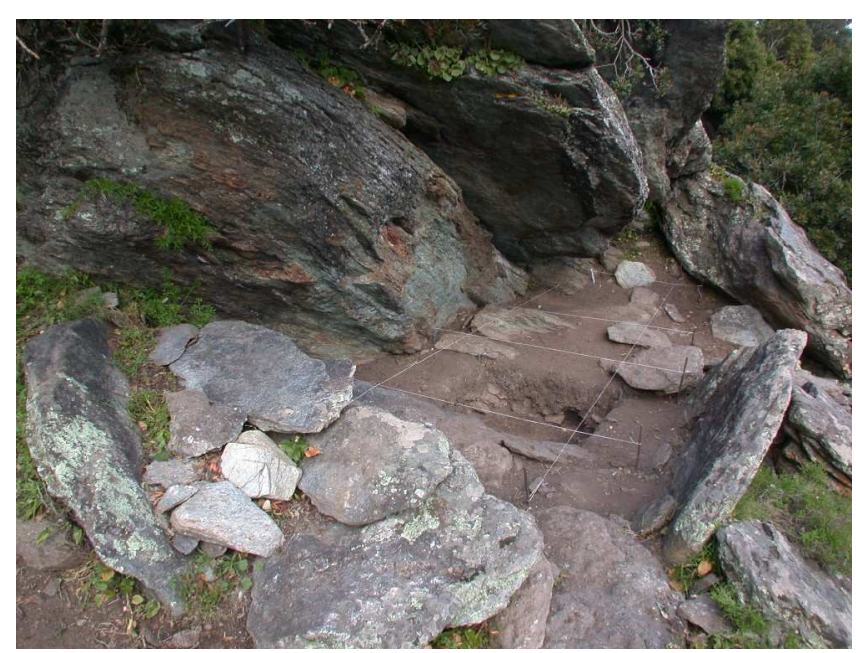

Fig. 4. Implantation of the third excavation in the shelter (at the middle we can see the test excavation of the first campaign).

Two stratigraphic layers were recognized, they are unfortunately altered. Few vestiges were collected in the first layer, they are essentially fragments of modern glazed ceramics.

Layer II revealed a great quantity of material of various prehistoric and protohistoric times. However, in spite of the presence of many stones, no structure could be identified. Except the two stones set on edge which close the shelter in the south, the stones present inside can come from the disintegration of the rock or from a disrupted anthropic making.

The material discovered in this layer contains obsidian lithic vestiges. It is in majority fragments of blades (Fig. 5, $\mathrm{n}^{\circ} 3$ ) or microblades, we can also note the presence of a scraper on a the distal part of a blade (Fig. 5, $\mathrm{n}^{\circ} 2$ ) and retouched flakes (Fig. 5, ${ }^{\circ} 4$ ). Three flint vestiges were also brought to light, among which a stemmed projectile point with obtuse shoulders (Fig. 5, $\mathrm{n}^{\circ} 1$ ). Several pebbles, or fragmented pebbles, were discovered as well as rhyolite flakes sometimes retouched (Fig. $5, n^{\circ} 5$ ).

We discovered often eroded cob elements and many ceramics shards, among which we find especially rims (Fig. $\left.5, \mathrm{n}^{\circ} 11-21\right)$, in particular of curved form with rounded lips. They indicate that the containers had an average diameter from 15 to $20 \mathrm{~cm}$. The discovered bases are flat, the handles are in "ruban" and the shoulders are frequent. The decorations are represented by cordons sometimes incised and perpendicular (Fig. 5, ${ }^{\circ} 6$ and 9) and two shards have incised lines and cupuled points (Fig. 5, $\mathrm{n}^{\circ} 7$ and 8).

Several metal vestiges were also collected, in particular 2 small chains ( 21 and $17 \mathrm{~mm}$ in length) and 13 rings (Fig. 5, $\mathrm{n}^{\circ} 23$ ) or fragments of rings ( $2 \mathrm{~mm}$ in thickness and $7.5 \mathrm{~mm}$ in diameter in average), a fragment of fibule (Fig. 5, $\mathrm{n}^{\circ} 22$ ) and fragments of stem as well as a blue pearl in molten glass (9 $\mathrm{mm}$ in diameter and $3 \mathrm{~mm}$ in thickness) (Fig. 5, $\mathrm{n}^{\circ} 24$ ). 


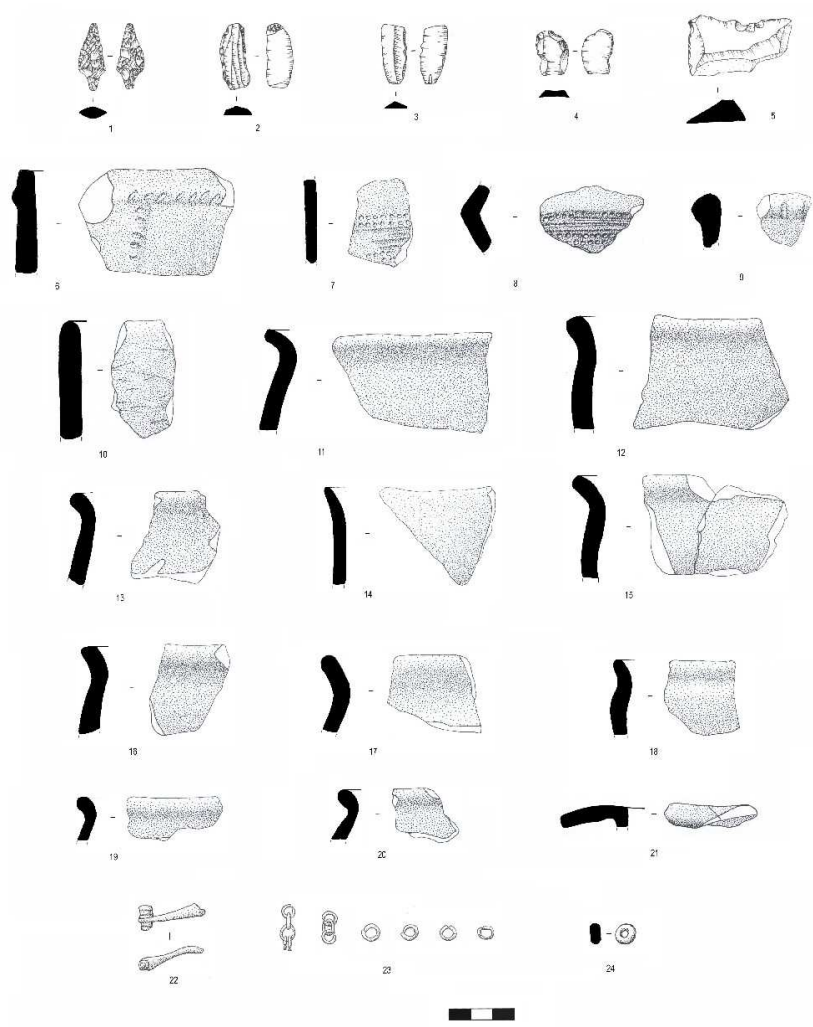

Fig. 5. Material of the third excavation. 1 : flint projectile point; $2-4$ : obsidian artefacts; 5 : retouched rhyolite flake; $6-10:$ decorated shards; 11 -

21 : rims; 22 et 23 : metallic vestiges; 24 : molten glass pearl.

The vestiges brought to light correspond to different periods of occupation; the lithic material refer to the Neolithic, certain ceramic decorations probably date from the Bronze Age and the metal elements or in glassmaking are attributable to the Iron Age. The filling of the shelter was thus altered, undoubtedly at an old time.

The presence of the stones set on edge, the discovery of metal vestiges, of the pearl in molten glass and of calcined osseous remains, of very small dimensions, indicate that the shelter was probably used at the Iron Age as a burial. It represents of a major element since no indication of the occupation of the site at this period had been identified before and no burial of this time is listed to our knowledge in the mico-area.

\section{CHRONOLOGICAL SYNTHESIS OF THE MATERIAL}

Even if a great part of the material discovered on the site comes from altered levels or from fieldwalking [3], the operations carried out enables to define the principal characteristics of the occupations which followed one another.

For the Neolithic, the occupation is characterized by the preponderance of the obsidian like raw material, nearly 800 elements were collected on the site. The presence of nucleus indicates that the work of the obsidian took place on the site.
The tools are in majority made up of fragments of blades, microblades or flake-blades and the tools (burin, scraper, borer) are very often produced starting from these supports. The morphology and the size of the discovered projectile points are very variable, they are stemmed but with obtuse or straight shoulders, of foliaceous form or more rarely with barbs, for a size between $1.5 \mathrm{~cm}$ and $3 \mathrm{~cm}$.

The quantity of the obsidian vestiges and the typology of the found tools make us attach these elements to the Middle or Final Neolithic $\left(4^{\text {th }}-3^{\text {rd }}\right.$ millennium B.C. $)$. They are indeed reminiscent of discoveries carried out on sites of habitat of the island of these periods, in particular at Monte Grossu (Biguglia, Haute-Corse) [4] and at Basi (Serra-di-Ferro, Corse-du-Sud) [5].

The flint vestiges, although all were discovered in two shelters of the south-west sector, are very different; as well in the nature of the material as in the typology of the objects: debris presenting a cortical part at the projectile point. The low number of flints, only 4 elements, does not enable us to link them with one precise chronological period. However, these vestiges are most frequently discovered in a Neolithic context [6].

In the same way, the vestiges in rhyolite (36 fragments) are certainly attributable to the Neolithic but this rock is still used at the beginning of the Bronze Age [6]. However we note their scarcity, the diversity of the types of rhyolites employed, and the small proportion of tools (2 projectile points), they are generally debris or flakes sometimes retouched.

The characteristics of ceramics discovered are the preponderance of the everted rims and the flat bases. The ceramic decorations most represented are the cordons, the majority seems horizontal, sometimes they are incised or impressed. These types of vestiges being present as soon as the Neolithic and during the Bronze Age, it is not possible to replace them chronologically [6].

Ceramics of the Neolithic seem not easily identifiable. We note the presence of grooved or incised decorations and shards with fine paste which, just like the obsidian vestiges, could be attached to an advanced Neolithic [6].

The occupation of the Bronze Age ( $2^{\text {nd }}$ millennium B.C.) is characterized by the presence of ceramics with cordons with finger-nail impressions. But this decorative technique does not appear "standardized", types of varied impressions (circular, oval, dissymmetrical...) are found on different pastes. Similar ceramic vestiges were identified in Corsican sites [7] but also in the Tyrrhenian area [8], on the whole of the Bronze Age. Also let us note that the majority of the shards discovered have a rather thick paste (more than $1 \mathrm{~cm}$ ), which is rather regarded as characteristic of the Bronze Age.

The Iron Age ( $1^{\text {st }}$ millennium B.C.) is attested by vestiges that we find in insular funerary contexts [9]. Their discovery in an arranged shelter confirms this assumption. However, 
the low number and the very fragmented or eroded state of the vestiges do not allow us a more precise chronological determination. No indication lets suppose that the plateau was used as a habitat at this period, this assumption cannot however be isolated.

These first observations require to be replaced in a more precise chronological context, in order to better identify the evolutions of the material cultures and exchanges.

\section{ENVIRONEMENTAL CONTEXT}

The site is between two different natural environments, the plain and the mountainous sector. Each one offers considerable natural resources for the subsistence of a community and its supply in raw materials. We tried to evaluate the potentialities of exploitation of the area according to the supposed activities of the inhabitants and the source of the found vestiges.

During the Neolithic and the Bronze Age, where the site was used as a habitat, the strategies of subsistence were based on a economy of production, but the predatory activities were still present [6].

Several zones seem favourable to agricultural activities, in particular the slopes of the relief where the site is. However it is a small alluvial plain located in the south which seems most favorable to this type of activity. Indeed, these level and irrigated lands are only $2 \mathrm{~km}$ from the site.

Concerning pastoralism, the possible zones of pastures could be the littoral hills located in the east and the heights of the two valleys which are in the west.

Hunting and gathering must have been practised in these same adjacent valleys, which because of the strong unevenness, seem hardly favourable to other exploitations.

The frequentation of the two valleys close to the settlement is confirmed by the discovery, in a small shelter of $1043 \mathrm{~m}$ in altitude, of a fragment of polished axe, very similar to an element found on the site.

The site overhanging the plain, it is thus near quaternary deposits rich in clay, thus allowing to provide for the needs of the group for the realization of ceramics and cob. The nature of the tempers of several shards, had been the subject of an analysis of thin-sections ${ }^{2}$. Five shards present tempers of local origin, some could be taken directly on the site because they do not have any trace of wearing away. Other tempers underwent a river or marine erosion, but their nature indicates that they can come from the surroundings of the site. Only one shard poses problem, the temper is partly

2 The thin-section carried out by Mr. Berlinghi Antoine, assistantengineer, litholamellor, Laboratoire des Sciences de la Terre, Université de Corse. Determinations carried out by Mrs. Spella Marie-Madeleine, M.C. (H.D.R.), Laboratoire des Sciences de la Terre, Université de Corse. made up of not eroded local rocks, but also of eroded rocks which would come from the volcanic complex of Monte Cinto. If we privilege a local origin, the layer from which they come can be either an outcrop of the area, but they are rare, or they could be collected in the alluvia of Golo or Tavignano, since in fact the closest rivers that transport such rocks.

The discovered vestiges in obsidian, rhyolite and flint include either nucleus or debris presenting a cortical part, which indicate that the knapping stone took place on the site. The possible localization of provisioning are different for these three rocks. The nearest flint layers are in Tuscany and in the north of Sardinia. In the same way, the origin of the obsidian is probably to seek in Sardinia, like the analyses carried out on other sites of the Middle Neolithic of the island showed [10]. The vestiges in rhyolite could come from a conglomerate of pebbles, which is located $10 \mathrm{~km}$ in the South. A comparison between the found vestiges and various qualities of rhyolite present on this site lets appear many similarities. Also let us point out this settlement is quiet wellsupplied in quartz pebbles, elements which we find on the site. Moreover, this settlement went through a prehistoric frequenting, as the discovered obsidian vestiges attest it. However the most important layers of rhyolite are located in the north-west part of the island.

Fragments of ground stones, mano, strikers and a perforated pebble known as in "hard stones", consist of metabasalt, metadolerite or metagabbros. We find these rocks, on the site even for the metagabbros, but especially in the massif of Negrine $4 \mathrm{~km}$ in the South. These polished vestiges could also be taken in the bed of the rivers which come from this sector.

The majority of the supply in raw material can thus have a local origin (Fig. 6), but the discovery of alien vestiges proves the integration of the inhabitants of the site to the circulations of materials and the cultural currents which cross the Tyrrhenian area. 


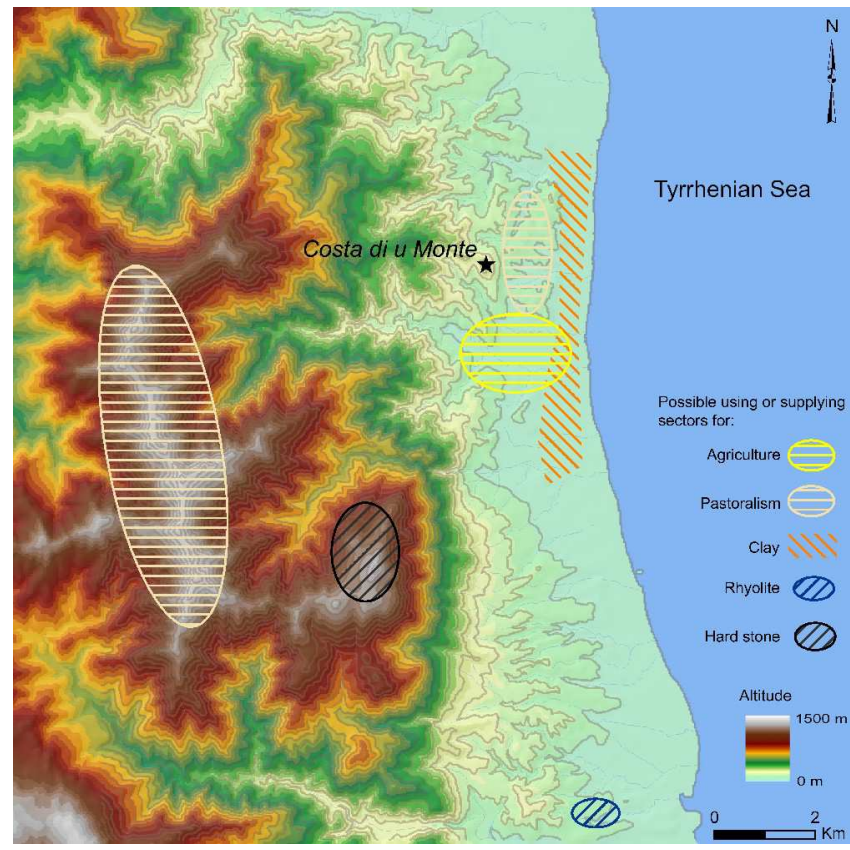

Fig. 6. Map of the exploitation potentialities of the near environment of the site, i.e. between the Fiumalto and Alesani rivers.

\section{CONCLUSION}

The first results of the studies of the site of Costa di u Monte underline its scientific interest. This settlement with a vast surface area which dominates east side of Corsica, delivered an abundant material. It was thus used as a habitat during the Middle or Final Neolithic and at the Bronze Age, and as a place of burial at the Iron Age.

If the collected vestiges can in their majority come from the immediate environment of the site, certain elements attest to the existence of relations, exchanges of raw material (obsidian, flint) and stylistic influences (ceramic decorations), with other Mediterranean regions.

This site thus allows to better apprehend the Prehistory and Protohistory of this part of the island within the Tyrrhenian area.

The various analyses engaged on the material discovered in excavation (datings of coals, taking away of sediments for palynologic analyses, source of lithic and ceramic materials) will soon bring answers on the chronology of the site, the exploitation of the environment and the exchanges.

\section{ACKNOWLEDGMENT}

The author thanks all the volunteers, students and amateurs, who took part in the excavation campaigns, and we gratefully acknowledge the contributions of C. Bain for her work on the original version of this document.

\section{REFERENCES}

[1] N. Marini, "Costa di u Monte (Poggio-Mezzana / HauteCorse) Rapport de fouille 2004," rapport remis au Service Régional de l'Archéologie, Direction Régionale des Affaires Culturelles, Ajaccio, Décembre 2004.

[2] N. Marini, "Costa di u Monte (Poggio-Mezzana / HauteCorse) Rapport de fouille 2005," rapport remis au Service Régional de l'Archéologie, Direction Régionale des Affaires Culturelles, Ajaccio, Décembre 2005.

[3] N. Marini, "Costa di u Monte (Poggio-Mezzana / HauteCorse) Prospection thématique," rapport remis au Service Régional de l'Archéologie, Direction Régionale des Affaires Culturelles, Ajaccio, Décembre 2003.

[4] J. Magdeleine, "L'occupation préhistorique au Monte Grossu I, et Monte Grossu II, commune de Biguglia Haute Corse," Archéologia Corsa, Etudes et Mémoires, n 4, pp. 23-42, 1979.

[5] G. Bailloud, "Fouille d'un habitat néolithique et torréen à Basi (Serra-di-Ferro, Corse),", Bulletin de la Société Préhistorique Française, tome 66, n³, pp. 367-384, 1969.

[6] F. Lanfranchi (de) and M.C. Weiss, L'aventure humaine préhistorique en Corse, Ajaccio, Ed. Albiana, 1997, 503 p.

[7] M-C Weiss, "L'Age du Bronze du Monte Ortu de Lumio: données récentes," Bulletin de la Société des Sciences Historiques et Naturelles de la Corse, n647, Bastia, pp. 57-92, 1984.

[8] D. Cocchi Genik (a cura di), Criteri di nomenclatura e di terminologia inerente alla dfinizione delle forme vascolari del Neolitico/Eneolitico e del Bronzo/Ferro, Atti del Congresso di Lido di Camairo 26-29 Marzo 1998, volume II, Firenze, Octavio, 1999, 534 p.

[9] M.-L. Marchetti, "Grotta Piatta new results from Corsican burials of the Iron Age," in Proc. 2006 ISEIM International Symposium on Environment Identities and Mediterranean area, to be published.

[10] R. Tykot, "New Approaches to the Characterization and Interpretation of Obsidian from the Mediterranean Island Sources," in P.B. Vandiver, M. Goodway, J.R. Druzik \& J.L. Mass (eds.), Materials Issues in Art and Archaeology VI. Warrendale, PA: Materials Research Society Proceedings 712: 143-157, 2002. [Online]. Available: http://luna.cas.usf.edu/ rtykot/Pubs.html 